\title{
THE CURRENT STATE OF ENGLISH-SLOVAK BILINGUAL EDUCATION IN SLOVAKIA
}

\author{
Veronika Szombatova
}

doi:10.18355/PG.2017.6.2.6

\begin{abstract}
The aim of the following article is to discuss the current status and the organization of bilingual English - Slovak secondary education in Slovakia as this area has not been examined and studied thoroughly. Not enough research has been conducted in this area and the only relevant data are we can rely on stem from implementing CLIL into all levels of education. Since bilingual education in Slovakia is increasing by leaps and bounds in recent years, we believe it is important to offer a deeper and an accurate insight of its contemporary position by analyzing as well as describing the organization of educational process. To fulfill the purpose of the research, Internet based research is developed as the main research tool. When implementing this research tool, our main interest will be dedicated to legal documents and statistical data regarding bilingual education in Slovakia.
\end{abstract}

\section{Key words}

bilingual education in Slovakia, types of bilingual education, analysis of the contemporary situation, legal foundations of bilingual education, Internet based research

\section{Introduction}

Teaching foreign languages belongs to the topics which has not lost its significance in Slovakia and throughout the whole world in recent years. One of the issues that certainly arouses attention within foreign language teaching over the last years and has also been the subject of intense debates is bilingual education. This is mainly due to fact that the number of children exposed to two languages is growing dramatically and this number is expected to rise even more in the next decades.

Furthermore, a continuous growth of bilingual schools is also motivated by the guidelines of the European Union that is trying to govern all its efforts towards a multilingual society. Currently, the ability to speak two languages is not seen just as a benefit of being privileged, but rather as a necessity to find a prosperous job. The issue of bilingual education in Slovakia is also closely related to the opening of borders and the increasing migration of population. As a result of aforementioned, educational institutions are trying to adapt to this trend and promote bilingual education in all types of schools, from pre - school institutions to secondary schools.

An increasing number of bilingual language schools as well as bilingual sections within state schools naturally invoke theoretical as well as methodological questions regarding this type of education, which need to be answered in detail. 
The topic of English - Slovak bilingualism is quite new in Slovakia, not enough research has been undertaken in this area and as a result of this, there is still a lack of appropriate teaching materials, strategies and methodological resources that bilingual teachers could draw on. Moreover, bilingual education is a field full of paradoxes that need to be proved in order to require credible information.

Because of the previously mentioned issues regarding bilingual education investigation, it is really necessary to provide more information in order to ensure successful foreign language learning and teaching. The presented article deals with this very issue. The forthcoming part will be aimed at the analysis of such issues regarding bilingual education in Slovakia that need to be examined.

\section{The Notion of Bilingual Education and Its Legal Foundations}

Baker (2011) outlines bilingual education is just "a simplistic label for a complex phenomenon"covering different types of bilingual education. What all bilingual programs have in common is that they integrate two languages for giving instructions. Therefore, Mejia (2002) points out the objectives of such programs are not just linguistic (as it is usual for language learning) but also academic, especially in the content subjects.

In a broader sense, a widely accepted definition of bilingual education refers to that kind of education that is provided in two different languages (Pokrivcakova, 2013). However, the issue takes on different meanings in different countries and it is therefore considered much complicated.

In the most general meaning, Cohen (1975) claims bilingual education involves all those types of education in which at least a part of school curriculum or all of it is taught in foreign language regardless of the combination of mother tongue and foreign language. In other words, academic content is taught in two languages, the native and the foreign language, with varying extent of each language used within particular bilingual education program. Baker and Prys Jones (1998) point the use of two languages as a medium for presenting school curriculum can be seen as a medium to develop full bilingualism and biliteracy.

Pokrivcakova (2013) gives a very precise distinction between the forms of bilingual education based on the mutual relationships of the languages that are used to mediate the academic content:

a) mother tongue + foreign language (in case of educating students of Slovak nationality, when a part of the curriculum subjects is taught in Slovak and some subjects (at least three) in a foreign language;

b) mother tongue + state language (applied within the educational system of national minorities, if their language is recognized as an official language of teaching instructions);

c) state language + foreign language (this form of bilingual education is typical for those students, whose mother tongue is not recognized as an official teaching language in Slovakia, and therefore, education is held in the state language and a part in a foreign language).

As for the education in Slovakia, only the first of the above mentioned form of bilingual education is recognized as truly bilingual according to the school 
legislative. The law concerning bilingual education defines bilingual education as such education in which mother tongue and foreign language are combined for teaching school curriculum (Act on Schools, Law 245/2008, § 6).

Talking about the establishment of bilingual schools in Slovakia, there are two ways of providing bilingual education. In the past, bilingual education was strictly bound to intergovernmental agreements, however, in the present it can be provided by any school that can provide education in foreign language at least in three compulsory subjects (Act on Schools, Law $245 / 2008, \S 7)$.

In 2003, legislation concerning specific aspects of bilingual education has been developed to build up more sustainable and compatible system of bilingual schools. The legislation covers official state policy concerning curriculum, entrance exam, assessment and leaving exam specifics. Based on this legislation, educational aims for particular schools were formulated, tailored specifically for each school.

\section{The Development of Bilingual Education in Slovakia}

Language learning has undoubtedly become one of the top priorities in Slovakia after the collapse of communism in 1989 accompanied by major social, political and economic changes. As a result of this, the first bilingual schools were set up in 1990s. These schools were set up in cooperation with the target language country on the base of bilateral agreement and provided native speakers for both foreign language and content subject teaching. In majority of schools with bilingual sections, the curricula were put together by combining Slovak educational system together with that of the target country. Recently, several bilingual sections have been established regardless of any foreign partner. There is no more a condition to involve foreign countries in order to set up this kind of school, each school is responsible for providing teaching at least three content subjects in foreign language. Due to this varieties of bilingual schools can be found across Slovakia.

Generally speaking, Laukova (2007) perceives bilingual schools based on intergovernmental agreements to be of higher quality by claiming they are more challenging and demanding for their students. They may have their distinctive specifics that do not necessarily correspond with the state educational program, and therefore time allocated to foreign languages teaching may not coincide with the framework curriculum for grammar schools with two languages of instruction. These schools follow study programs that are officially recognized by the ministries of education of both participating countries. An advantage of bilingual schools based on intergovernmental agreements is that a foreign partner guarantees foreign teachers of vocational subjects as well as foreign textbooks, exchange of experience, exchange programs for students and internships for teachers at partner schools of the country.

Regarding the second type of bilingual education in Slovakia, which not based on intergovernmental agreements, Pokrivcakova (2013) mentions at least three compulsory subjects have to be taught in foreign language and the 
maximum number of subjects is not given. Schools do not need to have foreign lecturers, so Slovak teachers with a university degree teach compulsory subjects in foreign language. These schools strictly follow laws regulating education in Slovakia.

\section{Definition of the Research Problem}

A credible research reflecting the conditions and contemporary state of bilingual education in Slovakia is still not sufficient because of couple of reasons. The most striking is that there are not enough schools providing bilingual type of education for a long period of time, so therefore there is a lack of information that would be so solid the researchers could draw on and create a relevant sample.

So far the majority of relevant data referring to the area of bilingual research in Slovakia is concerned with the following topics (primarily associated with CLIL method): a case study of bilingual education in Slovakia (Pokrivcakova, 2012), analysis of CLIL teacher competencies (Hurajova, 2012; Sepesiova, 2014; Hurajova, 2016), measuring efficiency of CLIL implementation (Luprichova, 2013; Kovacikova, 2012), innovations and creativity connected with CLIL (Sepesiova, 2014), CLIL research in Slovakia (2013), experimental verification of CLIL method (Menzlova, 2016), CLIL method implemented in ESP teaching (Chmelikova, 2016), the importance of educational assessment in CLIL (Sepesiova, 2016) and teacher training in CLIL (Pokrivcakova, 2015).

As there is still a low number of projects and research dedicated to bilingual education, it results in a lack of proved information that would form a reliable base. We can draw on just the research handling the method of CLIL from various viewpoints, therefore some significant key aspects of bilingual education remain unconfirmed and unexplained. It is however crucial to "fill in this gap" since there has been noticed a rapid growth of bilingual schools in Slovakia that seek for valid and reliable information to insure quality of bilingual education.

\section{The main research aims}

1 To map the situation concerning English - Slovak bilingual secondary grammar schools in Slovakia according to their main characteristics.

2 To describe the current status and organization of bilingual education in Slovakia.

\section{Methods of Gathering Data}

In order to provide a better picture about the contemporary position of English - Slovak bilingual secondary grammar schools in Slovakia, we have decided to implement Internet based research, focusing on the national documents and statistical data referring to this type of education. The chosen research method is supposed to serve as the main tool to fulfill the above stated aims of our research. 


\section{The State of Art of Bilingual Education in Slovakia}

In the following part, our main focus will be on English - Slovak bilingual grammar schools in Slovakia. We need to differentiate between two main types of bilingual grammar schools in Slovakia. Those who were established in $90 \mathrm{~s}$ on the base of bilateral agreement are considered to be of higher quality. They provide teaching at least six content subjects in English language. The other types of bilingual grammar schools have been set up recently after a big boom in foreign language learning. In this case, students learn usually three content subjects in foreign language and sometimes a combination of English and Slovak language is used to mediate particular subject content.

The above mentioned types of bilingual grammar schools in Slovakia follow different types of laws and regulations. School curriculum in bilingual grammar schools based on bilateral agreement comes from the foreign partner country, which determines the composition of content subjects taught in English. The later type of bilingual schools respects the School Act in Slovak Republic according which any three content subjects must be taught in English in order to establish a bilingual grammar school. Therefore, the composition of content subjects varies mainly according to the availability of qualified teachers.

When comparing bilingual grammar schools with ordinary grammar schools, another difference lies in school leaving examination. Students who attend secondary grammar schools with English bilingual sections have to take leaving examination at $\mathrm{C} 1$ level according to the CEFR. The exam consists of two parts - a written part including tasks aimed at testing reading and listening skills, grammar and vocabulary, writing and essay; and a spoken part consisting of contrasting a set o pictures, speaking about a given topic and a simulation on a given topic. The written part of leaving exam is created by the National Institute for Certified Educational Measurements and all students take it at the same time within 90 minutes. The spoken part lasts for 40 minutes - 20 minutes preparation and 20 minutes of monologue or dialogue with three members of the leaving examination commission.

Balazova (2013) indicates differences concerning the graduation of bilingual students by writing that after graduating, students of bilingual education obtain a double school report - one Slovak and one in accordance with the criteria of a foreign partner. Graduates reach $\mathrm{C} 1$ level according to the Common European Framework for Languages, which equals to state language exam.

Pokrivcakova (2013) and Vyhlaska Ministerstva skolstva Slovenskej republiky (437/2009 Z.z.) summarize several qualifications and specific qualification requirements for bilingual education teachers. For bilingual education in Slovakia it is typical that is implemented in monolingual classes and two languages, native and foreign, are used for giving instructions. Teachers of content subjects teach in a foreign language, however, they are usually not the native speakers but they are qualified teachers of those content subjects with excellent communication skills in the foreign language. Teaching qualification for teaching a foreign language is not a requirement and also teachers who have not finished university studies in particular 
foreign language can use this language for teaching content subjects, however, they need to prove their ability to master at least $\mathrm{C} 1$ level of foreign language. Therefore, they usually decide for passing language state exams at this level.

In case of the qualified teachers for bilingual education, especially content subjects, the teachers are not trained in the methodology, so the teaching practice can be described as experimental. Laukova (2007) encourages teachers to attend courses aimed at bilingual education methodology (especially CLIL), provided by qualified teaching institution, e.g. British Council or actively participate in various Comenius and Erasmus+ courses focusing on various specifics of CLIL and bilingual education.

Statistical data analysis from school year 2016/2017 (Statisticka rocenka gymnazia, 2016) shows there are 68 bilingual grammar schools in Slovakia, either based on intergovernmental agreements or established as bilingual sections within grammar schools, 43 of them with English as a foreign language. This number is expected to grow dramatically in the following years. Other bilingual grammar schools combine Slovak as mother tongue together with French (5), German (5), Spanish (7), Russian (3), Italian (1) and other (4).

The number as well as the structure of subjects taught in foreign language varies of different bilingual schools. Particular subjects and their scope are provided by each bilingual school in their school educational program. Each school implementing bilingual education specifies the number and structure of content subjects taught in foreign language as well as time allocated to individual content subject in each grade of study. In the majority of bilingual grammar schools, usually science content subjects are taught in foreign language, so especially mathematics, physics, chemistry, biology and geography. However, the range of subjects taught in foreign language differs and depend on personal capacities.

To briefly illustrate the boom of establishing bilingual grammar schools in Slovakia, the following charts provide an overview of their gradual increase since the school year 1991 up to the present. The charts include the total number of all bilingual grammar schools (later BGS) and the number of English - Slovak bilingual schools in Slovakia in particular school years.

The charts depict a gradual raise in the number of BGS set up in the Slovak Republic. We can see that at the beginning of the chart (the school year 1991/1992), there were only 2 English - Slovak BGS out of 10 which provided bilingual education in foreign languages. By the school year $2016 / 2017$, the number of all BGS in Slovakia is seven times bigger as they are 68 together. Regarding the current number of English - Slovak BGS, they are 43 together, which is four times more than at the beginning. 


\begin{tabular}{|c|c|c|c|c|c|c|c|c|c|c|c|c|c|}
\hline $\begin{array}{c}\text { School } \\
\text { year }\end{array}$ & $2016 / 17$ & $2015 / 16$ & $2014 / 15$ & $2013 / 14$ & $2012 / 13$ & $2011 / 12$ & $2010 / 11$ & $2009 / 10$ & $2008 / 09$ & $2007 / 08$ & $2006 / 07$ & $2005 / 06$ & $2004 / 05$ \\
\hline $\begin{array}{c}\text { Number of } \\
\text { BGS }\end{array}$ & 68 & 59 & 52 & 51 & 48 & 44 & 41 & 36 & 34 & 34 & 33 & 29 & 28 \\
\hline $\begin{array}{c}\text { English - } \\
\text { Slovak } \\
\text { BGS }\end{array}$ & 43 & 40 & 34 & 32 & 30 & 26 & 23 & 18 & 15 & 15 & 15 & 12 & 12 \\
\hline
\end{tabular}

Figure 1 Representation of a gradual increase of bilingual grammar schools from 2004 to the present

\begin{tabular}{|c|c|c|c|c|c|c|c|c|c|c|c|c|c|}
\hline $\begin{array}{c}\text { School } \\
\text { year }\end{array}$ & $2003 / 04$ & $2002 / 03$ & $2001 / 02$ & $2000 / 01$ & $1999 / 00$ & $1998 / 99$ & $1997 / 98$ & $1996 / 07$ & $1995 / 06$ & $1994 / 05$ & $1993 / 04$ & $1992 / 03$ & 1991/02 \\
\hline $\begin{array}{c}\text { Number of } \\
\text { BGS }\end{array}$ & 24 & 24 & 20 & 19 & 17 & 15 & 13 & 12 & 12 & 12 & 10 & 10 & 10 \\
\hline $\begin{array}{c}\text { English - } \\
\text { Slovak } \\
\text { BGS }\end{array}$ & 10 & 10 & 7 & 6 & 5 & 4 & 4 & 4 & 4 & 4 & 2 & 2 & 2 \\
\hline
\end{tabular}

Figure 2 Representation of a gradual increase of bilingual grammar schools from 1991 to 200

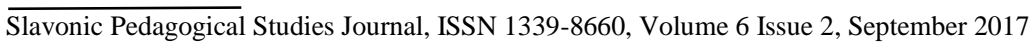




\section{English-Slovak bilingual grammar schools}

The following part aims to look closer at English - Slovak BGS. As we have stated in the previous part, there are 43 currently. The charts depict the main characteristics of English - Slovak BGS for each Region in Slovakia (they are 8 together).

\begin{tabular}{|c|c|c|c|}
\hline \multicolumn{4}{|l|}{ BRATISLAVA REGION } \\
\hline Name of school & Established & $\begin{array}{l}\text { State/ } \\
\text { Private/ } \\
\text { Church }\end{array}$ & $\begin{array}{l}\text { Primary school } \\
\text { (PS)/ } \\
\text { kindergarten } \\
(\mathrm{K})\end{array}$ \\
\hline $\begin{array}{l}\text { 1. Gymnázium, Bilíkova 24, } \\
\text { Bratislava }\end{array}$ & $2008 / 2009$ & $\mathrm{~S}$ & \\
\hline $\begin{array}{l}\text { 2. Gymnázium, Pankúchova } 6 \text {, } \\
\text { Bratislava }\end{array}$ & 2011/2012 & $\mathrm{S}$ & \\
\hline $\begin{array}{l}\text { 3. Bilingválne gymnázium C.S. } \\
\text { Lewisa, Bratislava }\end{array}$ & $2004 / 20015$ & $\mathrm{P}$ & PS \\
\hline $\begin{array}{l}\text { 4. Evanjelické } \quad \text { lýceum, } \\
\text { Bratislava }\end{array}$ & $1991 / 1992$ & $\mathrm{C}$ & PS \\
\hline $\begin{array}{l}\text { 5. Súkromné gymnázium, Česká } \\
\text { 10, Bratislava }\end{array}$ & $2005 / 2006$ & $\mathrm{P}$ & PS, K \\
\hline $\begin{array}{l}\text { 6. Gymnázium, Tilgnerova 14, } \\
\text { Bratislava }\end{array}$ & $2013 / 2014$ & $\mathrm{P}$ & PS \\
\hline $\begin{array}{l}\text { 7. Spojená škola Novohradská - } \\
\text { Gymnázium } \quad \text { Jura } \text { Hronca, } \\
\text { Bratislava }\end{array}$ & $1994 / 1995$ & $S$ & PS \\
\hline 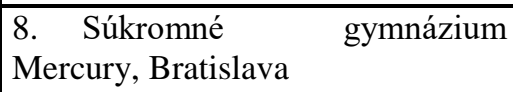 & $2010 / 2011$ & $\bar{P}$ & PS, K \\
\hline $\begin{array}{l}\text { 9. Galileo School, Dudvážska } 6 \text {, } \\
\text { Bratislava }\end{array}$ & $2005 / 2006$ & $\mathrm{P}$ & PS, K \\
\hline
\end{tabular}

\section{Figure 3 English-Slovak bilingual grammar schools in Bratislava Region}

The smallest region in Slovakia called Bratislava Region contains 9 BGS, 3 of them are state schools, 1 is church and the rest 5 schools are private. Regarding their tradition, we can see that there are also BGS with a longer history, since two schools were set up in 1991/1992 and 1994/1995. What is quite interesting is the fact that 7 out of 9 schools presented in the chart above are merged with primary schools and 3 are even merged with kindergartens. Preschool and primary school educational stages are typically merged with higher secondary school educational stage when it comes to private and church schools, but the chart shows an exception. 


\begin{tabular}{|l|l|l|l|}
\hline \multicolumn{5}{|l|}{ TRNAVA REGION } & Established & $\begin{array}{l}\text { State/ } \\
\text { Private/ } \\
\text { Church }\end{array}$ & $\begin{array}{l}\text { Primary school } \\
\text { (PS)/ } \\
\text { kindergarten } \\
\text { (K) }\end{array}$ \\
$\begin{array}{l}\text { 1. Gymnázium Ivana Kupca, } \\
\text { Hlohovec }\end{array}$ & $2016 / 2017$ & $\mathrm{~S}$ & - \\
\hline $\begin{array}{l}\text { 2. Gymnázium Pierra de } \\
\text { Coubertina, Pieštany 2015/2016 }\end{array}$ & $\mathrm{S}$ & \\
\hline $\begin{array}{l}\text { 3. Gymnázium Jána } \\
\text { Baltazára Magdina, Vrbové }\end{array}$ & $2012 / 2013$ & $\mathrm{~S}$ & \\
\hline $\begin{array}{l}\text { 4. Gymnázium Jána Hollého, } \\
\text { Trnava }\end{array}$ & $2015 / 2016$ & $\mathrm{~S}$ & \\
\hline $\begin{array}{l}\text { 5. BESST: Anglicko - } \\
\text { Slovenská bilingválna škola, } \\
\text { Trnava }\end{array}$ & $2014 / 2015$ & $\mathrm{P}$ & PS, K \\
\hline $\begin{array}{l}\text { 6. Súkromné gymnázium, } \\
\text { Hodská 10, Galanta }\end{array}$ & $2000 / 2001$ & $\mathrm{P}$ & \\
\hline
\end{tabular}

\section{Figure 4 English-Slovak bilingual grammar schools in Trnava Region}

The chart above portrays BGS in Trnava Region. This Region contains 6 BGS, 4 of which are state schools and 2 are private. There are currently no church - founded BGS. All six schools were established after 2000, so they do not have so long tradition. Only one BGS, which is private, is merged with both a primary school and a kindergarten.

\begin{tabular}{|c|c|c|c|}
\hline \multicolumn{4}{|l|}{ TRENČÍN REGION } \\
\hline Name of school & Established & $\begin{array}{l}\text { State/ } \\
\text { Private/ } \\
\text { Church }\end{array}$ & $\begin{array}{l}\text { Primary school } \\
\text { (PS)/ } \\
\text { kindergarten (K) }\end{array}$ \\
\hline $\begin{array}{l}\text { 1. Gymnázium, Jablonská 5, } \\
\text { Myjava }\end{array}$ & 2011/2012 & $\mathrm{S}$ & \\
\hline $\begin{array}{l}\text { 2. Súkromné } \\
\text { Futurum, Trenčín }\end{array}$ & $2007 / 2008$ & $P$ & PS \\
\hline
\end{tabular}

Figure 5 English-Slovak bilingual grammar schools in Trenčín Region

The above depicted chart shows 2 BGS in Trenčín Region. Both BGS were founded after 2000, so they do not have a long tradition. One of them is a state school and the other one is a private school. The private one is also merged with a primary school. 


\begin{tabular}{|l|l|l|l|l|}
\hline \multicolumn{2}{|l|}{ NITRA REGION } & Established & $\begin{array}{l}\text { State/ } \\
\text { Private/ } \\
\text { Church }\end{array}$ & $\begin{array}{l}\text { Primary } \\
\text { school (PS)/ } \\
\text { kindergarten } \\
\text { (K) }\end{array}$ \\
\hline $\begin{array}{l}\text { 1. Gymnázium, Mládežnícka 22, } \\
\text { Sahy }\end{array}$ & $2014 / 2015$ & $\mathrm{~S}$ & \\
\hline $\begin{array}{l}\text { 2. Gymnázium, Golianova 68, } \\
\text { Nitra }\end{array}$ & $2013 / 2014$ & $\mathrm{~S}$ & \\
\hline
\end{tabular}

Figure 6 English-Slovak bilingual grammar schools in Nitra Region

The chart shows 2 BGS in Nitra region, which were set up in 2013 and 2014. Both of them are state, neither of them is merged with a primary school nor with a kindergarten.

\begin{tabular}{|c|c|c|c|}
\hline \multicolumn{4}{|l|}{ ŽILINA REGION } \\
\hline Name of school & Established & $\begin{array}{l}\text { State/ } \\
\text { Private/ } \\
\text { Church }\end{array}$ & \begin{tabular}{|l} 
Primary \\
school (PS)/ \\
Kindergarte \\
n $(\mathbf{K})$
\end{tabular} \\
\hline $\begin{array}{l}\text { 1. Gymnázium Jozefa Miloslava } \\
\text { Hurbana, Čadca }\end{array}$ & $2002 / 2003$ & $S$ & \\
\hline $\begin{array}{l}\text { 2. Evanjelické } \quad \text { gymnázium, } \\
\text { Martin }\end{array}$ & $2013 / 2014$ & $\mathrm{C}$ & PS, K \\
\hline $\begin{array}{l}3 \text { Evanjelická spojená škola, } \\
\text { Liptovský Mikuláš }\end{array}$ & $2009 / 2010$ & $\mathrm{C}$ & PS \\
\hline $\begin{array}{l}\text { 4. Bilingválne gymnázium } \\
\text { Milana Hodžu, Sučany }\end{array}$ & $1991 / 1992$ & $S$ & \\
\hline \begin{tabular}{lr}
$5 . \quad$ Súkromné & \multicolumn{2}{c}{ bilingválne } \\
gymnázium, & Bystrická \\
Ružomberok &
\end{tabular} & $2010 / 2011$ & $\mathrm{P}$ & \\
\hline $\begin{array}{l}\text { 6. Súkromné gymnázium, } \\
\text { Oravská cesta 11, Žilina }\end{array}$ & $1994 / 1995$ & $P$ & \\
\hline
\end{tabular}

\section{Figure 7 English-Slovak bilingual grammar schools in Žilina Region}

The table above shows 6 BGS in Žilina Region. 2 schools are private, 2 state and 2 church. One church school is merged with a primary school and a kindergarten and the other church school is merged with a kindergarten. This Region contains two of the oldest founded BGS in Sučany and Žilina with a good reputation. 


\begin{tabular}{|l|l|l|l|}
\hline PREŠOV REGION & Established & $\begin{array}{l}\text { State/ } \\
\text { Private/ } \\
\text { Church }\end{array}$ & $\begin{array}{l}\text { Primary school } \\
\text { (PS) or } \\
\text { Kindergarten } \\
\text { (K) }\end{array}$ \\
\hline $\begin{array}{l}\text { 1. Gymnázium Leonarda } \\
\text { Stöckela, Bardejov }\end{array}$ & $2015 / 2016$ & S & - \\
\hline $\begin{array}{l}\text { 2. Gymnázium sv. Jána } \\
\text { Zatoústeho, Humenné }\end{array}$ & $2016 / 2017$ & S & \\
\hline $\begin{array}{l}\text { 3. Gymnázium, svätej } \\
\text { Konštantínova 2, Prešov }\end{array}$ & $2014 / 2015$ & C & \\
\hline $\begin{array}{l}\text { 4. Gymnázium } \\
\text { Moniky, Prešov }\end{array}$ & $2010 / 2011$ & S & \\
\hline $\begin{array}{l}\text { 5. Súkromné gymnázium Life } \\
\text { Academy, Poprad }\end{array}$ & $2006 / 2007$ & P & PS, K \\
\hline $\begin{array}{l}\text { 6. Súkromná spojená škola, } \\
\text { European English School, } \\
\text { Prešov }\end{array}$ & $2009 / 2010$ & P & PS \\
\hline $\begin{array}{l}\text { 7. Cirkevné gymnázium sv. } \\
\text { Mikuláša, Stará Lubovnna }\end{array}$ & $2015 / 2016$ & C & \\
\hline
\end{tabular}

Figure 8 English-Slovak bilingual grammar schools in Prešov Region

The chart shows 7 BGS in Prešov Region, which were established gradually, so some of them have longer tradition and some of them are quite new. Out of 7 schools, 3 are state, 2 are private and the remaining 2 are church schools. One private school is merged with both a primary school and a kindergarten and another one also with a primary school.

\begin{tabular}{|l|l|l|l|}
\hline BANSKÁ BYSTRICA REGION & Established & $\begin{array}{l}\text { State/ } \\
\text { Private/ } \\
\text { Church }\end{array}$ & $\begin{array}{l}\text { Primary school } \\
\text { (PS) of } \\
\text { Kindergarten } \\
\text { (K) }\end{array}$ \\
\hline $\begin{array}{l}\text { Name of school Evanjelické gymnázium } \\
\text { Tisovec }\end{array}$ & $2011 / 2012$ & $\mathrm{C}$ & - \\
\hline $\begin{array}{l}\text { 2. Evanjelické gymnázium } \\
\text { Banská Bystrica }\end{array}$ & $2011 / 2012$ & $\mathrm{C}$ & \\
\hline $\begin{array}{l}\text { 3. Gymnázium Andreja } \\
\text { Kmet'a, Banská Štiavnica }\end{array}$ & $2010 / 2011$ & $\mathrm{~S}$ & \\
\hline
\end{tabular}

Figure 9 English-Slovak bilingual grammar schools in Banská Bystrica Region 
The chart above shows BGS in Banská Bystrica Region. They are 3 together, all founded after 2010, so they do not have a long history. Two of them are church school, one is state and none of them is merged with a primary school or a kindergarten.

\begin{tabular}{|c|c|c|c|}
\hline \multicolumn{4}{|l|}{ KOŠICE REGION } \\
\hline Name of school & Established & $\begin{array}{l}\text { State/ } \\
\text { Private/ } \\
\text { Church }\end{array}$ & $\begin{array}{l}\text { Primary } \\
\text { school (PS) or } \\
\text { Kindergarten } \\
(\mathbf{K})\end{array}$ \\
\hline $\begin{array}{l}\text { 1. Gymnázium, Trebišovská } 12 \text {, } \\
\text { Košice }\end{array}$ & $2012 / 2013$ & $\mathrm{~S}$ & \\
\hline $\begin{array}{ll}\text { 2. Súkromné } & \text { gymnázium } \\
\text { Futurum, Košice } & \end{array}$ & $2012 / 2013$ & $\mathrm{~S}$ & \\
\hline $\begin{array}{l}\text { 3. Gymnázium, Opatovská cesta } \\
\text { 7, Košice }\end{array}$ & $2014 / 2015$ & $\mathrm{~S}$ & \\
\hline $\begin{array}{lll}\text { 4. Gymnázium, Javorová } & 16, \\
\text { Spišská Nová Ves } & & \\
\end{array}$ & $2011 / 2012$ & $\mathrm{~S}$ & \\
\hline $\begin{array}{l}\text { 5. Gymnázium, Komenského 32, } \\
\text { Trebišov }\end{array}$ & $2012 / 2013$ & $\mathrm{~S}$ & \\
\hline $\begin{array}{l}\text { 6. Súkromné gymnázium, Katkin } \\
\text { park II, Košice }\end{array}$ & $2006 / 2007$ & $\mathrm{P}$ & \\
\hline $\begin{array}{l}\text { 7. Evanjelické gymnázium J.A. } \\
\text { Komenského, Košice }\end{array}$ & $1994 / 1995$ & $\mathrm{C}$ & \\
\hline $\begin{array}{lll}\text { 8. Gymnázium } & \text { P.J. } & \text { Šafárika, } \\
\text { Rožňava } & & \\
\end{array}$ & $2014 / 2015$ & $\mathrm{~S}$ & \\
\hline
\end{tabular}

\section{Figure 10 English-Slovak bilingual grammar schools in Košice Region}

The above shown chart demonstrates BGS in Košice Region. It contains 8 BGS, 6 of them are state, 1 is private and 1 is church. None of the BGS is merged with a primary school or a kindergarten. All schools were founded after 2010, except one established in 1994.

\section{Conclusion}

This paper attempts to describe the current status and organization of bilingual grammar schools in Slovakia using Internet based research as the main research method for gathering and analyzing available data. It also states the peculiarities concerning bilingual education at grammar schools, such as the requirements for the teachers and students. To sum up our findings regarding the situation of English - Slovak bilingual education in Slovakia, there are 43 BGS, out of which 8 are church schools, 22 state schools and the remaining 13 are private schools. The most BGS (9) are located in the smallest Region called Bratislava, while in Nitra Region there are only two BGS, which are both state. The number of BGS merged with kindergarten is 6 , while those which are merged with primary schools are 13 . The most BGS merged with kindergarten and/or primary school occur in 
Bratislava Region, while there are such regions (Nitra, Košice, Banská Bystrica) in which none of BGS is merged with either a primary school or a kindergarten. Speaking about the activity of particular BGS, 6 out of 43 were established between 1991 and 2000, 12 BGS were founded between the years 2001 and 2010 and the majority (25) was set up after 2011. We expect this number is going to rise in the following years. Therefore, this type of education urgently requires a more complex research to ensure the quality of bilingual education. Further research should definitely be conducted in the area of designing school curricula, several evaluation criteria, specific characteristics of bilingual students, comparing students from different bilingual schools, etc.

\section{Bibliographic references}

Act on Schools, Law 245/2008. Available online: https://www.minedu.sk/d ata/att/5682.rtf

BALAZOVA, D. 2013. Budu sa sprisnovat' kriteria pre dvojjazycne skoly? Pravda.Available online: http://spravy.pravda.sk/domace/clanok/282205budu-sa-sprisnovat kriteria-pre-dvojjazycne-skoly

BAKER, C. 2011. Foundations of Bilingual Education and Bilingualism”, Clevedon: Multilingual Matters.

BAKER, C. - PRYS JONES, S. 1998. Encyclopedia of Bilingualism and Bilingual Education. Multilingual Matters. ISBN:1853593621

COHEN, A. 1975. A Sociolinguistic Approach to Bilingual Education. Rowley, Mass.: Newbury House.

HURAJOVA, A. 2015. An Overview of Models of Bilingual Education.

Mediterranean Journal of Social Sciences, Vol 6 No 6, p. 186 - 190. ISSN 2039-9340.

LAUKOVA, D. 2007. Windows on CLIL: Slovakia. Available online: http://archive.ecml.at/mtp2/CLILmatrix/DOCS/Windows/Windows\%20on\% 20CLIL\%20Slovakia.pdf

MEJIA, A. 2002. Power, Prestige, and Bilingualism: International Perspectives on Elite Bilingual Education. Clevedon: Multilingual Matters.

POKRIVCAKOVA, S. 2013. Priprava ucitelov na bilingvalne vzdelavanie. In: Teoria a prax pripravy buducich translatologov a ucitelov anglickeho jazyka. Available online: http://www.fhv.umb.sk/katedry/katedra-anglistikya-amerikanistiky/ medzinarodnaelektronicka-konferencia-25-26-jun-2013/

Statisticka rocenka gymnasia. 2016. Available online: http://www.cvtisr.sk/cvti-sr-vedeckakniznica/informacie-oskolstve/statistiky/statisticka-rocenka-publikacia/statisticka rocenkagymnazia.html?page_id=9599

Vyhlaska Ministerstva skolstva Slovenskej republiky, 437/2009 Z.z.: Available online: https://www.minedu.sk/data/att/2967.pdf

Mgr. Veronika Szombatová

Constantine the Philosopher University, Faculty of Pedagogy

Department of Language Pedagogy and Intercultural Studies

Dražovská 4, Nitra, Slovakia

veronika.szombatova@ukf.sk 